\title{
THE DEVELOPMENT OF THE CONCEPT OF CONSTITUTIONAL DAMAGES
}

\author{
by Wesley Martin Grimm*
}

Any question dealing with the development of law requires, by its very nature, a discussion of sometimes factually distinguishable but legally interwoven points; thus focus is placed on the law of constitutional damages. Every effort is made to present cases in a manner that solidifies an argument of progress and refinement in relation to the concept of constitutional damages as a remedy. The anchor of this work is the Constitution. ${ }^{1}$ Fose, ${ }^{2}$ the locus classicus on constitutional damages, introduces the notion of constitutional damages as a remedy in South African litigation and is threaded throughout this work. Strong reliance is placed, inter alia, on the decisions of Kate, ${ }^{3}$ Modderklip, ${ }^{4}$ Dikoko, ${ }^{5}$ and Mboweni. ${ }^{6}$ The thrust of my argument is that the remedy of constitutional damages should only be relied upon when most appropriate and practical to ensure the vindication of constitutional rights in light of the facts of a particular case and alternative legal remedies.

\section{Origins: The Constitution and Fose}

In a constitutional democracy like South Africa founded on human dignity, the achievement of equality and the advancement of human rights and freedoms has direct reliance on the very basis of our new dispensation, the Constitution. The Constitution not only allows litigants to enforce but also to vindicate their rights. ${ }^{7}$

Indeed, the Constitution permits a court to grant 'appropriate relief, including a declaration of rights' to litigants seeking to enforce their rights in manner that the court views as 'just and equitable'.8 Based on the aforementioned the court in Fose found that constitutional damages do in principle fall under the umbrella of

Fourth year LLB Student at the University of Pretoria.

The Constitution of the Republic of South Africa, 1996, 'The Constitution'.

Fose $v$ Minister of Safety \& Security 19973 SA 786 (CC) 'Fose'.

MEC: Welfare $v$ Kate 20064 SA 478 (SCA) 'Kate'

President of the Republic of South Africa $\vee$ Modderklip Boerdery (Pty) Ltd 20055

SA 3 (CC) 'Modderklip'.

Dikoko v Mokhatla 20066 SA 235 (CC) 'Dikoko'

Minister of Police $v$ Mboweni \& Another 20146 SA 256 (SCA) ‘Mboweni'.

The Constitution sec 1(a) \& (c).

The Constitution sec 38 (note this was contained in sec 7(4)(a) of the Interim Constitution of 1993); The Constitution sec 172(1)(b)(ii). 
appropriate relief but this remedy's practical application would depends on the facts of each particular case and the particular right(s) infringed upon. 9 The court in Dikoko held that the same considerations in respect of 'appropriate relief' as under section $7(4)$ (a) of the interim constitution apply under section 38 of the Constitution when an award of damages is necessary to protect and enforce rights encapsulated in the Bill of Rights. ${ }^{10}$ But is an award of damages by the constitutional court necessarily constitutional damages? What does 'constitutional' damages refer to?

It must be noted at this early point that the principle of subsidiarity has diffused so effectively into the area of constitutional litigation that it may be considered trite law and is of consideration in this instance. The Jayiya case, ${ }^{11}$ on appeal, explained this principle in a constitutional damages context, albeit obiter, where the Court held that constitutional damages as envisaged in Fose might be awarded as appropriate relief where no statutory remedies have been given or no adequate commonlaw remedies exist. ${ }^{12}$ Deduced from this is that where parliament has legislated statutory mechanisms to enforce and vindicate constitutional rights they must be used to the extent that they are consistent with the constitution. ${ }^{13}$ Additionally, it is worth bearing in mind that in most cases where a constitutional right has been infringed and loss occasioned a delictual action will lie. ${ }^{14}$

\section{An appropriate remedy must be an effective remedy}

The focus of this work is the development of the remedy of constitutional damages. Out of necessity any appropriate relief - be it legislative, delictual or constitutional - must be effective relief. ${ }^{15}$ When is relief seen to be 'effective'? Courts have a particular responsibility to ensure that the values underlying the rights entrenched in the Constitution can be effectively vindicated by creating innovative remedies where appropriate. ${ }^{16}$ Harms JA in Modderklip deals with this point adeptly by reiterating that it is the duty of the court to mould an order that will provide effective relief

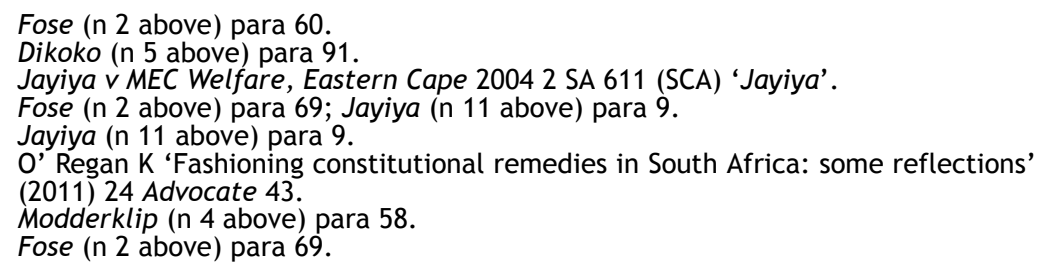


to those affected by a constitutional breach without being overawed by practical problems. ${ }^{17}$ In so doing the real world will be synchronised with the ideal construct of a constitutional world. ${ }^{18}$ Harms JA therefore appears to imply that the constitutional damages remedy will be the most appropriate where and when it is the most practical remedy in a given set of facts. ${ }^{19}$

\section{Constitutional damages: The interface of remedy \& rights}

As practicality is important in the fashioning of constitutional damages and the peculiar facts of different cases are therefore determinative in such claims, certain factual circumstances are now presented. The factual discussion begins with Modderklip and ends with the unreported case of Ngomana. ${ }^{20}$

In Modderklip, where the inability of a landowner to enforce an eviction order against occupiers of an informal settlement on his land was at issue, constitutional damages were awarded in the form of a fair rental value for the duration of the unlawful occupation of the plaintiff's private property in violation of the constitution. ${ }^{21}$ The constitutional rights in question were those of property, housing and human dignity. Constitutional damages were held to be the most appropriate remedy, as neither could the lawful eviction order be practically executed nor did the state attempt to lawfully expropriate the land from the plaintiff. ${ }^{22}$

In Kate, dealing with damages resulting from the failure of the state to pay social assistance benefits which were due, an amount of money equal to the interest payable when money unlawfully withheld was awarded as constitutional damages. ${ }^{23}$ This case dealt with the infringement of the plaintiff's constitutional right to social security and related to her right to human dignity. ${ }^{24}$ Constitutional damages were found to be the most appropriate and most practical relief for the following reasons: the plaintiff did not have the wherewithal and capacity to enforce her rights through a mandamus ${ }^{25}$ and a declaration of rights is most suitable to clarify and provide legal

Modderklip SCA (n 17 above) para 25

Ngomana v CEO South African Social Security Agency 23036/09 2010 ZAWCHC 172 (13 September 2010): unreported case 'Ngomana'.

Modderklip (n 4 above) para 65 \& 66; The Constitution s25(1) and s26(1)-(3).

Modderklip (n 4 above) para 64.

Kate (n 3 above) para 33.

Kate (n 3 above) para $1 \& 33$; The Constitution s27(1)(c) and s10.

Kate (n 3 above) para 31. 
guidance to resolve an underlying dispute where government officials comply voluntarily, promptly and in good faith. ${ }^{26}$

In Fose constitutional damages were held not to be appropriate as the compensatory function of the law of delict provided sufficient vindication of the infringed constitutional right. ${ }^{27}$ The action in that case arose out of the alleged assault and torture of the plaintiff by unknown members of the South African Police Services, infringing on the plaintiff's rights to human dignity, freedom and security of the person, privacy and lawful detention. ${ }^{8}$

Dendy saw a failed attempt at a claim for constitutional damages for alleged injury to the constitutional right of human dignity flowing from an unsuccessful job application process. ${ }^{29}$ The court emphasised the test of what is the appropriate relief to vindicate and protect the infringed rights. ${ }^{30}$

In Darson ${ }^{31}$ constitutional damages for loss of profit were held not to be an appropriate remedy due to the practical difficulty to calculate it without providing evidence. The constitutional right to fair administrative action was in question in that case which dealt with review proceedings by an unsuccessful tenderer to a civil engineering contract. ${ }^{32}$ The decision to award the tender was made by the wrong official and consequently breached the constitutional right to fair administrative action. ${ }^{33}$

Dikoko dealt with a delictual claim of defamation. ${ }^{34}$ The constitutional rights in question were human dignity juxtaposed to and balanced against the right to freedom of expression. ${ }^{35}$ In referring to Fose the Court held that it would be strange if damages could not be claimed by a plaintiff to protect and enforce his fundamental rights. ${ }^{36}$ Interestingly the Court commented that the remedy of sentimental damages, though common law in origin, is also located within the ambit of 'appropriate relief' found in section 38 of the Constitution. ${ }^{37}$ The Court simply assumed in favour of the applicant that defamation could give rise to constitutional damages without finally deciding on the issue. ${ }^{38}$ Thus, helpful though the decision of

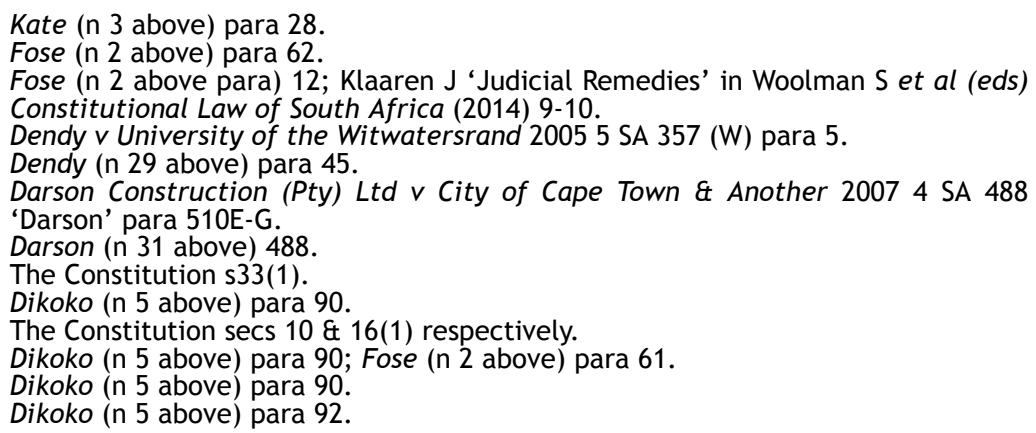


the court is, it ultimately is not a case of the successful application of the constitutional damages remedy. Resort was had to the usual delictual remedy in defamation matters namely the actio iniuriarum. ${ }^{39}$

Ngomana dealt with the same constitutional rights as Kate namely human dignity, access to social security and fair administrative action. ${ }^{40}$ The Court, in distinguishing between the two cases, held that in Kate the administrative process had run its course while in Ngomana several of the claims for constitutional damages were incidental to the principal relief sought by way of judicial review, that is, a review of decisions to refuse social assistance. ${ }^{41}$ The court held further that in cases like Kate, going forward, compliance with the Institution of Legal Proceedings Against Certain Organs of State Act (the Legal Proceedings Act) is required: that is to say proper notice and the constitutional damages claim must be framed as a 'debt' within the ambit of the Legal Proceedings Act. ${ }^{42}$ Failure to do so may still be condoned by the court. ${ }^{43}$ This compliance is now mandated by the Social Security Act. ${ }^{44}$

\section{Reflection on factual instances}

Flowing from these factual instances we see a pattern emerge: Firstly, all successful constitutional damages claims mentioned were against the state; secondly, the award of constitutional damages is discretionary in the sense that it is the facts and issues of practicality that mostly determine its application; thirdly the remedy of constitutional damages succeeded where it was most practical; and finally, the awards for constitutional damages were relatively small in quantum, for example the restriction on interest in the Kate order. ${ }^{45}$

As against this, Courts have refused to grant constitutional damages as a remedy for the following five reasons.

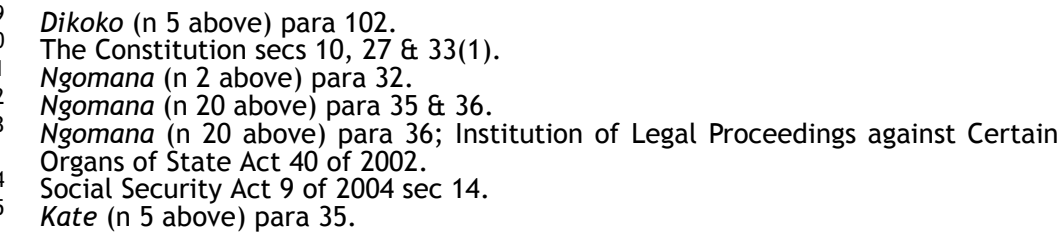




\section{Reasons for failed application of constitutional damages}

\subsection{Double remedy}

Constitutional damages should not be awarded in addition to statutory or common law damages as a penal vindication of constitutional rights. ${ }^{46}$ The Court in Fose reasoned that a substantial compensatory damages award is in and of itself a considerable vindication of infringed upon constitutional rights. ${ }^{47}$

\subsection{To serve a penal purpose}

Mokgoro $\mathrm{J}$ held for the majority (on the merits) in Dikoko that punishment and deterrence are functions of the criminal law and not the law of delict. ${ }^{48}$ This is consonant with what Ackermann $\mathrm{J}$ held in Fose in that constitutional damages as a penalty would result in a taking-over of criminal sanctions into the realm of civil law without the protective mechanisms afforded to alleged offenders. ${ }^{49}$

\subsection{Financial penalties and windfalls}

Ackermann $\mathrm{J}$ went on to find that, so far as could be ascertained, there is in our jurisprudence no indication that a substantial penal award against the state or an individual has any directly preventative effect; this notion is illusionary. ${ }^{50}$ Where a plaintiff is fully compensated for injuries sustained he needs no further financial windfall from relying directly on the Constitution as this will not guarantee a deterrent or preventative effect. ${ }^{51}$

\subsection{Exposure to double jeopardy}

If awarded in addition to compensatory damages then constitutional damages will have the effect that a party is 'punished' twice should such award be preceded or superceded by a criminal case with an equally adverse finding. ${ }^{52}$

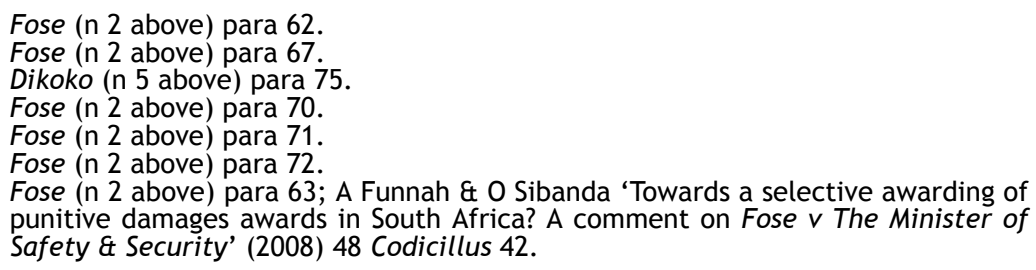

Fose (n 2 above) para 63; A Funnah \& O Sibanda 'Towards a selective awarding of punitive damages awards in South Africa? A comment on Fose $v$ The Minister of Safety \& Security' (2008) 48 Codicillus 42. 


\subsection{Subsidiarity and appropriateness}

Interlaced with the principle of subsidiarity is the notion that subject to its entrenched supremacy the Constitution does not deny the existence of any other rights that are recognised and conferred by, inter alia, the common law and legislation. ${ }^{53}$ The courts appear to interpret this to mean that recourse in a matter should at least in part first be had to remedies originating in legislation and/or the common law. ${ }^{54}$ Failing which and in circumstances where most appropriate and practical reliance on constitutional damages as a remedy may be had. ${ }^{55}$ The decisions of the court seem to suggest, in my view, that diligent counsel should plead constitutional damages in the alternate as the decision to award constitutional damages lies exclusively within the court's discretion. ${ }^{56}$

Following these limitations the question may now be asked: 'Going forward, how do I determine when constitutional damages should be pleaded?' The answer is to be found in the very recent case of Mboweni. ${ }^{57}$ The Court held in that case that in order to determine the question of remedy: firstly the relevant infringed constitutional right must be identified and pleaded or admitted facts must show infringement - simply put, the wrong must be identified; ${ }^{58}$ secondly, the damages must be causally linked to the wrong suffered, that is, the damage must flow from the infringement; ${ }^{59}$ thirdly, a court will ask in view of all circumstances of the particular case and other possible remedies whether the remedy of constitutional damages is the most appropriate and practical relief or whether the development of an existing common law (or statutory I argue) remedy is more appropriate to vindicate the right..$^{60}$

\section{Final remarks}

So it seems that where the legislature has expressly provided damages, à la the Promotion of Administrative Justice Act 3 of 2000, ${ }^{61}$ the resolution of the matter is simple: reliance must be placed on such a provision. ${ }^{62}$ This is in accordance with the principle of subsidiarity. In the absence of such express provision resort must then

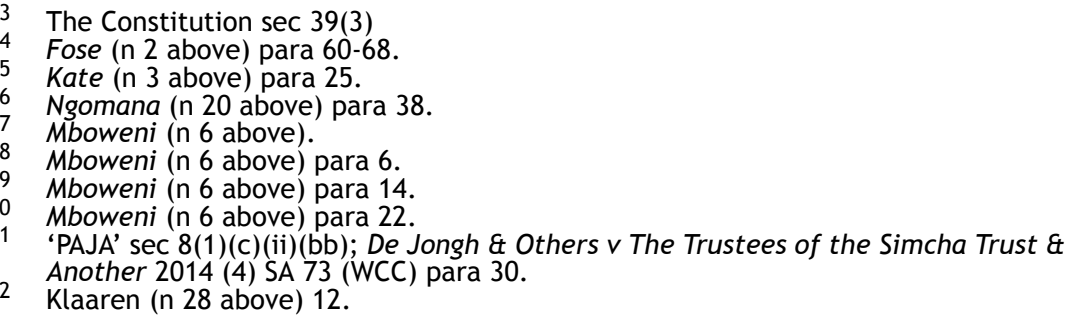


be had to whether the common law in its various and flexible forms provides for such a claim. ${ }^{63}$ This again takes account of the subsidiarity principle.

It would appear then that only on a broad assessment by the court, taking all socio-legal considerations into account as to a claim's reasonableness and justifiability, might a civil claim for damages to enforce constitutional rights succeed going forward ${ }^{64}$ This, however, is not the whole picture for it must be remembered that constitutional damages as a remedy falls under the umbrella of 'appropriate relief' that is 'reasonable and justifiable' and therefore cannot be considered a remedy of last resort. ${ }^{65}$ While the absence of other remedies may be a factor to be taken into account in the awarding of constitutional damages it is not decisive. ${ }^{66}$

The discretion to award constitutional damages in appropriate circumstances lies with the courts. ${ }^{67}$ Judicial restraint is mandatory in deciding these matters to ensure equity in litigation between plaintiff and defendant. Constitutional damages have become a recognised and applied remedy in South African jurisprudence. It is applicable where practical necessity demands its application to vindicate rights enshrined in the Bill of Rights as the most appropriate manner to do so - legally and factually.

Jayiya (n 11 above) para 9.

O' Regan (n 14 above) 45

Kate (n 3 above) para 27; The Constitution s38 \& s172(1).

O’ Regan (n 14 above) 45.

Klaaren (n 28 above) 13. 